Annals of Warsaw University of Life Sciences - SGGW

Land Reclamation No 38, 2007: 115-125

(Ann. Warsaw Univ. of Life Sci. - SGGW, Land Reclam. 38, 2007)

\title{
Brackish water ecosystem restoration based on integrated water system design
}

\author{
MARIJN KUIJPER, PERRY DE LOUW \\ TNO Geological Survey of The Netherlands The Netherlands,
}

\begin{abstract}
Brackish water ecosystem restoration based on integrated water system design. Despite their current location within a primary agricultural area, most of the creek remnants in the Dutch clay polder areas have a high potential for recovery into healthy ecosystems. Like most areas in the Netherlands the clay polders are densely populated. Therefore multifunctional land use is encouraged and different types of land use coexist within small distances from each other. As a result water conflicts occur: agricultural land use requires deep groundwater levels and causes eutrophication by spreading nutrients into the water system, while existing ecosystems within and around the creek remnants need wetland conditions and low nutrient levels. Furthermore periods of high discharge cause flooding of arable land. Extreme measures like filling in ditches and increasing water levels are needed to achieve the water targets for wetlands around the creeks. On the other hand, the effects of these measures easily cause water logging in nearby agricultural areas. We introduce an integrated approach for the restoration of creek ecosystems. Both the complex interaction of groundwater, surface water and ecology and the limiting conditions imposed by adjacent agricultural land use, spatial developments and regulatory settings like the European Water Framework Directive are thereby taken into account. A highly integrated set of measures is proposed creating optimal conditions for both high agricultural production and flourishing creek ecosystems.
\end{abstract}

Key words: brackish water ecosystems, integrated water management, agriculture and aquatic ecosystem relationships, ecosystems restoration.

\section{WESTERN BRABANT SEA CLAY POLDERS}

In the early 15th century the Dutch coastline consisted of natural fluctuating salt water marshes. Tidal fluctuations reached from 2.5 meters in regular situations up to 4 meters at storm surges. This resulted in the formation of deeply eroded tidal creeks and sea water inlets. Since the beginning of the 17th century people started to reclaim vast areas along the Dutch coast. Within four centuries the original salt water marshes in WestBrabant, the Netherlands, changed into a well organised "polder" system with highly regulated surface water levels. Reclamation of the land turned former sea water inlets into isolated creek remnants. Nowadays these creek remnants are still recognisable by their winding appearance, intersecting the rational system of straight canals and ditches. They are a significant part of the drainage system and the existence of brackish ecosystems within these creek remnants entirely depends on seepage of brackish groundwater.

Agriculture is the main land use in the sea clay polders, and water level regimes are adapted to provide optimal agricultural crop yields: deep winter water levels for fast drainage in wet periods and 
shallow summer water levels for water supply and irrigation in dry periods. But, like most areas in the Netherlands, the polders areas are densely populated. Therefore multifunctional land use is encouraged and different types of land use co-exist within small distances from each other. As a result Waterboard and Province have defined nature reserves in and around the creek remnants and concluded that, despite their current location within this primary agricultural area, most of the creek remnants have a high potential for recovery into healthy brackish wetland ecosystems. As a result water targets were formulated (Tab. 1) and the creeks were assigned ecological functions: low lying areas along the creeks should develop into healthy terrestrial ecosystems, consisting of a combination of reed marshes, swamps and alder woods. The aquatic creek system itself was assigned a fish habitat and together with the riparian zone it should provide an ecological migration route, connecting separated natural habitats, for both fish and terrestrial fauna.

\section{OBJECTIVE}

Potentials for creek restoration strongly depend on the interaction with nearby agricultural land use. Therefore a problem analysis was carried out, focussing on the following questions:

- Which water related problems, both agricultural and ecological, occur within this polder area?

- What are the potentials for restoration of natural creek ecosystems?

- Whichmeasurescanbetakentoachieve water targets for both agriculture and the creek ecosystems?

\section{INTEGRATED WATER SYSTEM ANALYSIS}

In order to answer the research questions and to achieve a better understanding of the polder water system, an integrated water system analysis was carried out focussing on the interaction of land use and water characteristics (both water quality and quantity). This

TABLE 1. Hydro-ecological targets for brackish creek ecosystems

\begin{tabular}{|c|c|c|}
\hline & \multicolumn{2}{|l|}{ Target } \\
\hline Hydrology & \multicolumn{2}{|c|}{$\begin{array}{l}\text { Flow velocity }<0.3 \mathrm{~m} / \mathrm{s} \\
\text { Feeding by brackish seepage water and fresh rain water } \\
\text { Winter groundwater level }<0.40 \mathrm{~m} \text { below surface level } \\
\text { Summer groundwater level } 0.4-2.0 \text { m below surface level }\end{array}$} \\
\hline Morphology & \multicolumn{2}{|c|}{$\begin{array}{l}\text { Mineral and organic substrate } \\
\text { Dynamic morphology (average sedimentation and erosion) }\end{array}$} \\
\hline Water quality & $\begin{array}{l}\text { Transparency }>0.4 \mathrm{~m} \\
\text { pH 7-9 } \\
\text { Oxygen } 70-120 \%\end{array}$ & $\begin{array}{l}\text { Chloride }>300 \mathrm{mg} / 1 \\
\text { Nitrogen }<2.2 \mathrm{mg} / 1 \\
\text { Phosphorous }<0.15 \mathrm{mg} / 1\end{array}$ \\
\hline Ecology & \multicolumn{2}{|c|}{$\begin{array}{l}\text { Associated vegetation: reed marshes, swamps and alder woods } \\
\text { Flora: Phragmites australis, Schoenoplectus lacustris, Ruppia maritima, Glaux } \\
\text { maritima } \\
\text { Fish: Gasterosteus aculeatus, Rutilus rutiles, Esox lucius } \\
\text { Birds: Haematopus ostralegus, Anser anser, Anas clypeata } \\
\text { Mammals: Microtus oeconomus }\end{array}$} \\
\hline
\end{tabular}


analysis comprised field measurements, groundwater modelling the analysis of water quality, creek bottom quality, ecological examinations and testing for the achievement of land use related water targets.

\section{FIELD MEASUREMENTS}

Field data were collected from shallow boreholes in transects perpendicular to the creeks:

- Description of the soil characteristics;

- Determination ofhistoricalgroundwater fluctuation from oxidation and reduction marks in the soil profile;

- Groundwater level measurements;

- Measurements of the current creek water level and elevation of the surface level along the creeks;

- Routing of electric conductivity (EC) measurements of both creek water and shallow groundwater below the creek bottom.

These data were used to distinguish major ongoing processes and were used as the validation data for a local groundwater model.

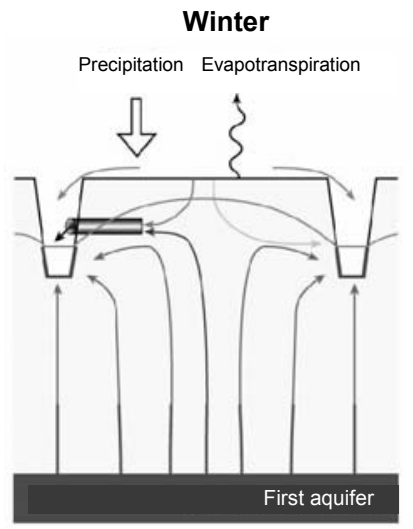

FIGURE 1. Local flow processes
Borehole observations show that the shallow subsurface consists of sea clay and sandy soils, containing shattered peat components. Most sand and silt deposits are found along former creek beds, while areas further from the creek are characterized by clay deposits. Observed oxidation and reduction marks are consistent with current observed groundwater levels ranging from 0.40 to 1.80 meter below surface level.

Field data also show that the creeks are an important part of the current polder drainage system. Creek water levels are therefore identical to levels in the surrounding ditches: deep winter levels to prevent water logging in periods of excessive rainfall and high summer levels to provide sufficient irrigation water in dry periods. This unnatural water regime has its impact on local groundwater flow systems. Figure 1 shows the existing flow processes on a local scale.

In a wet winter period, when surface water levels are kept low, the creeks provide drainage of precipitation water and seepage water. In a dry summer period, when surface water levels are maintained at a artificially high level,

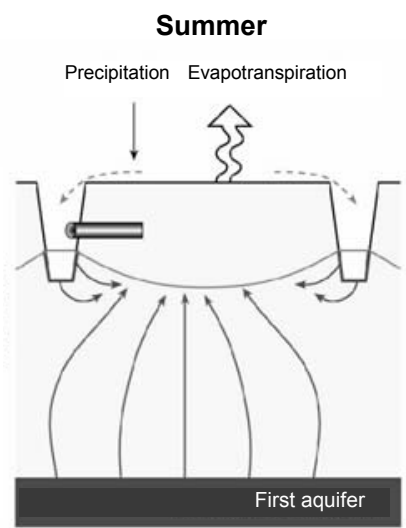


surface water infiltrates through the creek bottom and flows towards the middle of the field where it evaporates from the soil. In both situations the creeks are fed by brackish seepage water (Fig. 2).

Electrical conductivity measurements were used to verify the occurrence of brackish water in and around the creek system. Figure 3 shows the results of the EC-routing. Electric conductivity of both creek water and shallow groundwater below the creek bottom show values above $3000 \mu \mathrm{S} / \mathrm{cm}$ indicating the occurrence of brackish seepage water. EC profiles below the creek bottom show that chloride concentrations increase with depth up to $2000 \mathrm{mg} \mathrm{Cl}^{-} / 1$ at depths of one meter below the creek bottom.

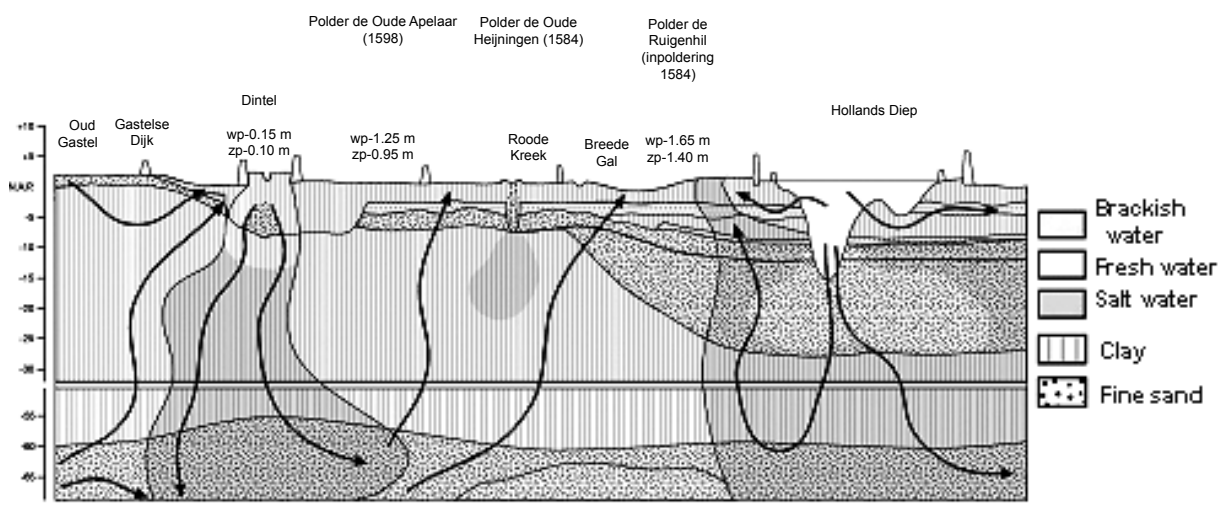

FIGURE 2. Regional groundwater flow in the polder system: seepage of brackish groundwater towards the polders and infiltration of fresh river water

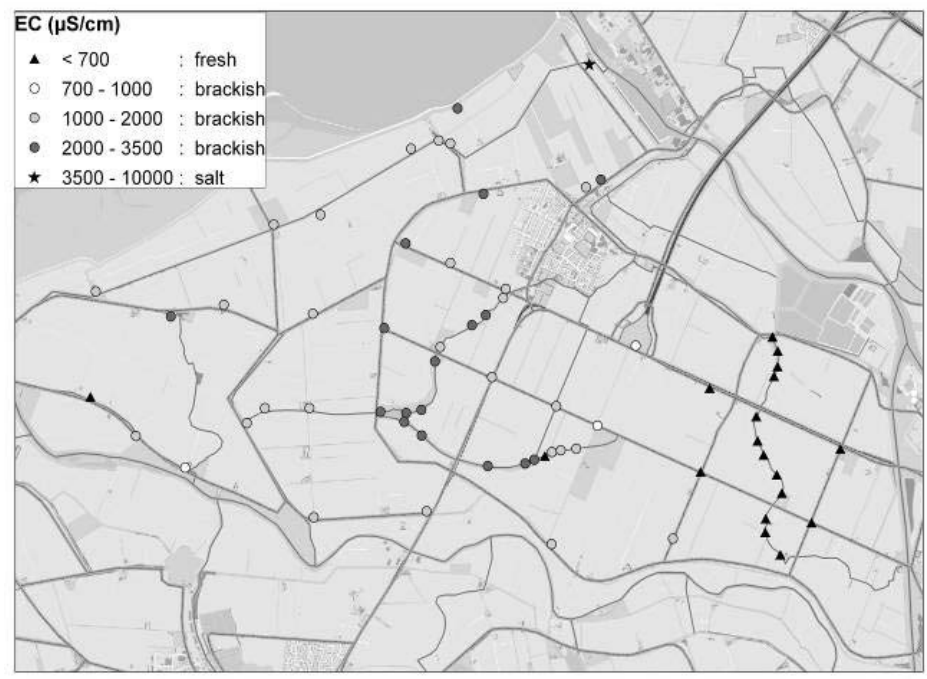

FIGURE 3. Electric conductivity of polder water 


\section{DETAILED GROUNDWATER MODEL}

A detailed $25 \times 25$ meter groundwater model (Modflow) was built for the polder area. The main purpose of this model was to obtain insight in the polder water flow system. The model was used to simulate the occurrence of the shallow groundwater levels, which form a boundary condition for wetland existence, and the occurrence of seepage water, which provides the creek ecosystems with brackish groundwater. In order to establish an accurate simulation of shallow groundwater levels and of the seepage of groundwater to the creek systems a detailed parameterisation of the geological subsurface was made. The hydraulic characteristics of the upper ten meters of the subsurface were attained by analysing sand and clay occurrences in hundreds of shallow boreholes available in the area. Beside geohydrological information, the location and drainage level of the local surface water system is a significant factor determining shallow groundwater depths. In order to simulate the non-linear behaviour of drainage systems, it is necessary to define river reach stages on a very detailed scale. River reach stages are therefore based on a very high resolution digital elevation model, containing one measurement per $16 \mathrm{~m}^{2}$. A filtering technique, described by Kuijper and te Stroet (2003), was used to remove all non-hydrological features and noise from the data set.

\section{AQUATIC ECOSYSTEM}

To determine the aquatic ecosystem conditions, creek water quality was analysed from surface water samples. Creek bottom composition was analysed by measuring nutrient load, heavy metals and PAK's. Furthermore, examinations of ecological health were made based on available macro fauna.

From combining the results of these three analyses it appeared that high nutrient levels, high saprobe levels and poor structure, caused by unnatural creek morphology and a lack of water vegetation, were the main problems for aquatic creek restoration.

The main sources of nutrients are agricultural land use, leading to surface and sub-surface runoff of nitrogen into the water system, and the seepage of nutrient rich groundwater, being the main input of phosphorous to the surface water system. High nutrient levels are unfavourable because of the resulting growth of algae, increasing saprobe levels and the drop of oxygen content in the water. The growth of algae will also results in an unbalanced fish population as it stimulates the growth of herbivorous, algae eating, fish populations over the carnivorous ones.

A lack of structure, caused by steep creek margins and unnatural water regimes and a lack of water vegetation causes a deficiency in shelter needed by fauna inside the creek system. Finally the presence of sluices, weirs and pumping stations forms an obstruction for fish migration to and from the creek system. 
POTENTIAL FOR

DEVELOPMENT OF TERRESTRIC WETLAND ECOSYSTEMS

Beside water quality, the potential for development of reed marshes, swamps and alder woods along the creek borders strongly depends on the average spring groundwater level and the occurrence of groundwater seepage (Wamelink and Runhaar, 2000). Results from field measurements and groundwater model calculations were used to analyse the depth of groundwater levels and the availability of groundwater seepage to the assigned ecosystems along the creek borders. It was concluded that sufficient groundwater seepage occurs into the creeks to sustain brackish ecosystems. On the other hand it turned out that water levels along the creek borders were too deep to meet the ecological needs (Fig. 4). Groundwater level raising measures like filling in ditches and increasing surface water levels are needed to achieve the water targets for the wetlands in and around the creeks.

\section{AGRICULTURAL YIELD}

Agricultural yield strongly depends on the combination of soil type and groundwater regime, the latter expressed as the average high groundwater level in winter and the average low groundwater level in summer. For every combination of soil type, and groundwater regime yield reductions due to excess water and due to drought have been derived by Brouwer and Huinink (2002). These yield reductions were documented in land use re-evaluation tables, the socalled 'HELP-tables'. In these tables yield reductions are expressed as a percentage of the practical potential crop yield. HELP-tables are available for most common combinations of crop and soil type.

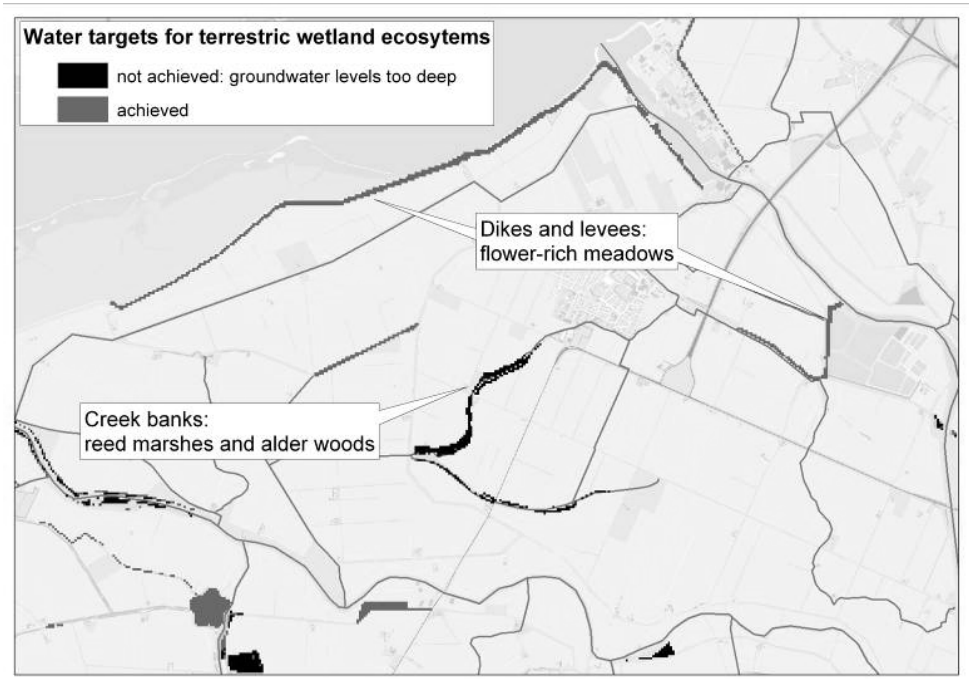

FIGURE 4. Water targets for terrestric wetland ecosystems 
Using the Brouwer and Huinink HELP-tables, current agricultural yields were determined, combining soil characteristics from the Soil Map of the Netherlands 1:50 000 with calculated groundwater levels from our groundwater model. From the yield determination it was concluded that in most areas water levels are optimally adjusted to the agricultural needs. No reductions due to high groundwater levels were found and in only a few areas drought related yield reductions up to $10 \%$ were calculated.

Although farmers seem to benefit from well adjusted groundwater levels, they do encounter some other water related problem. In periods of high rainfall intensity water logging occurs, caused by temporarily excess surface water. Furthermore, in dry periods low river water levels and the growth of cyanobacteria disturbs the inlet of fresh water, needed for both crop irrigation and for flushing of brackish water out of the polder water system.

\section{WATER CONFLICTS}

Combining model results and measurements, conflicting water targets are clearly illustrated (Fig. 5). As the entire water system was originally designed for agricultural land use, the main problems occur in achieving ecological targets. As illustrated above raising groundwater levels, by filling in ditches and increasing surface water levels is needed to achieve the water targets for the wetlands in and around the creeks. Such measures however will cause water logging in nearby agricultural areas.

Furthermore, raising surface water levels to establish high groundwater levels along the creek levees will also have its effect on the local groundwater flow situation: when surface water levels are raised above the hydraulic head of the underlying aquifer, seepage of brackish groundwater will be suppressed, resulting in a decrease in chloride content and eventually creating a fresh water fed creek system.

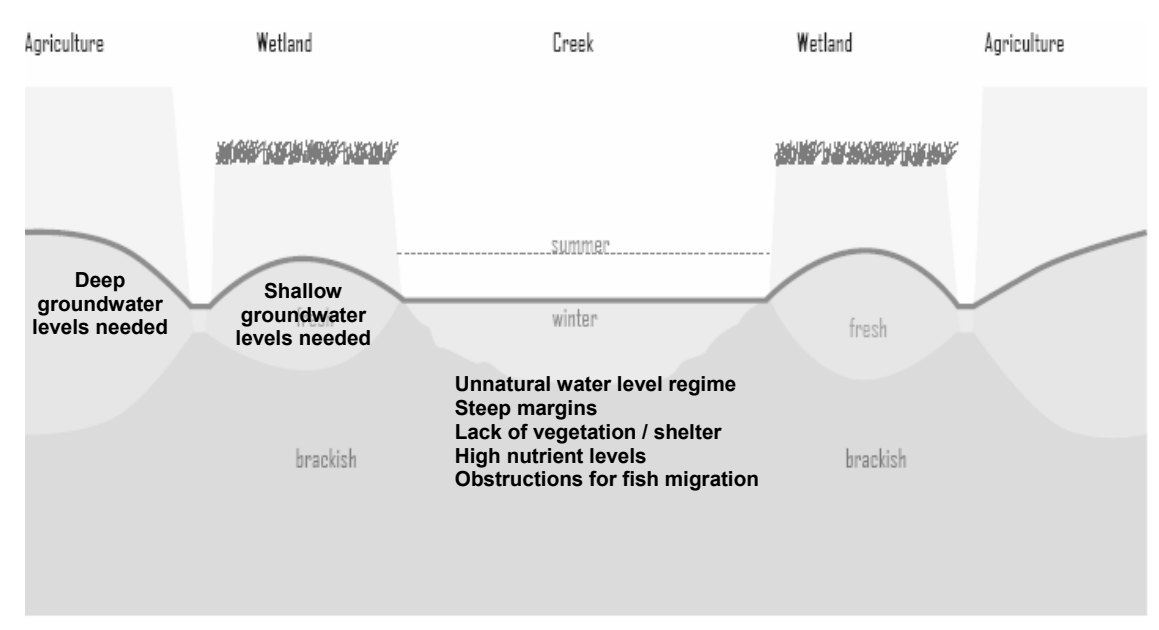

FIGURE 5. Water conflicts 
Agricultural land use on the other hand causes eutrophication of surface water and groundwater by emission of nutrients. This conflicts with the need of low nutrient levels imposed by both the regulatory settings from the European Water Framework Directive and the ecosystems requirements within and around the creeks.

\section{FINE-TUNING}

How to optimise ecological conditions, while maintaining agricultural yields? Fine-tuning of water system adjustments is needed to achieve optimal conditions for both high agricultural production and flourishing creek ecosystems. By combining technical eco-hydrological knowledge with the experience from local farmers and water managers several measures were defined.

\section{ISOLATING CREEKS}

The first measure is to isolate the creek system from the rest of the drainage system, using weirs. Isolation has several advantages. It creates the possibility to change the creek water level fluctuation into a more natural regime: high water levels in winter and low water levels in summer, while in the rest of the polder system water levels remain unaltered sustaining agricultural production.

Furthermore isolation make it possible to keep agricultural, nitrogen rich, drainage water out of the creek system, resulting in an improvement of water quality. The other source of nutrients, i.e. phosphorous rich groundwater seepage, is more difficult to reduce. Especially as the seepage of brackish groundwater forms the major boundary condition for brackish creek ecosystem restoration in this area. Although the nitrogen $(\mathrm{N})$ supply will be reduced after isolating creeks from the drainage system, the supply of phosphorous (P) might yet increase when seepage of brackish water is stimulated. More research is needed to make better predictions of the resulting $\mathrm{N}: \mathrm{P}$ ratio and to understand the effect it will have on the aquatic ecosystem.

Beside creek isolation, other measures like reduction of manure use, keeping parcel boundaries free from pesticides and stimulating the uptake of nutrients by reed beds serving as bio filters are taken into account, especially as the European Water Framework Directive does not focus on the creek ecosystems alone.

\section{REWETTING POSSIBILITIES}

With the raising of creek water levels it is possible to sufficiently rewet the creek sides and levees. But, when surface water levels are raised above the hydraulic head of the underlying aquifer, seepage of brackish groundwater will be suppressed. In this case two possibilities remain:

1. Raising water levels high enough to create wet land conditions, thereby repressing groundwater seepage and creating a rain fed, fresh water ecosystem in and around the creeks (Fig. 6a).

2. Raising water levels, but keeping them below the aquifers hydraulic head. In this case groundwater will discharge into the creek water system creating 
brackish water conditions in the creek itself. Along the creek borders either wet land conditions are not entirely met, so a dryer type of nature will establish there, or the raise in water levels can be combined by excavation of the creek sides and levees to create brackish, groundwater fed marsh conditions (Fig. 6b).

The likelihood of the second option strongly depends on the historical value of the creek margins. Should these flat margins remain recognisable landscape structures reminding us of the history of the polder areas or does the establishment of brackish conditions prevail? Both possibilities are now being analysed for their opportunities and risks.

\section{STRUCTURE AND MIGRATION IMPROVEMENT}

Beside hydrological measures more local measures can be taken to improve habitat properties and migration possibilities for fish and fauna living on the creek shores. A few examples are given.

Improvement of creek borders can be achieved by creating an alteration of steep and shallow margins, which provide shelter for fish and a habitat for water birds and macro fauna living on shallow water vegetation.

Creating some shallow pools along the creek margins improves migration possibilities for amphibians and small shrubs can provide shelter for small rodents like mice. The natural migration of fish can be assisted by placing fish passes around man-made barriers such as sluices, pumps and weirs

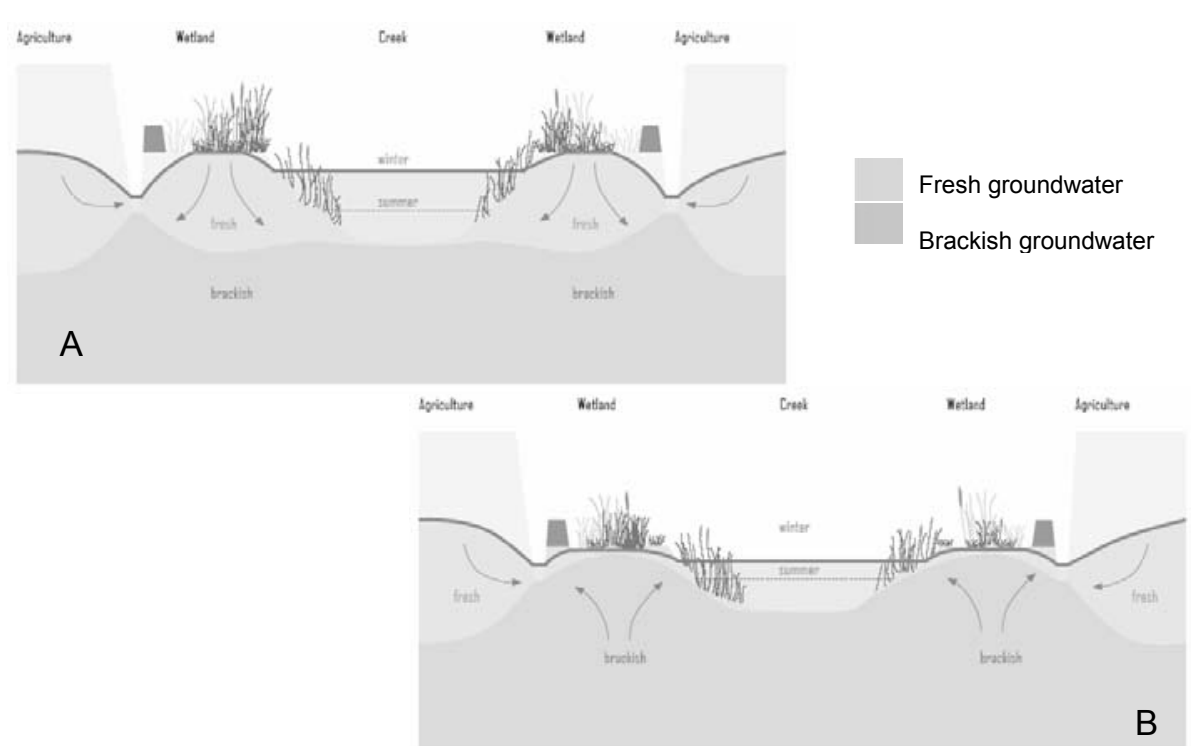

FIGURE 6. Two possibilities for creek restoration. A: fresh water system with high water levels. B: brackish conditions created by excavation of the creek sides and levees combined with lower water levels 


\section{CONCLUSIONS}

Despite their current location within a primary agricultural area most of the creek remnants in the West-Brabant sea clay polder areas have a high potential for recovery into healthy ecosystems. Extreme measures, however, like filling in ditches and increasing water levels are needed to achieve the water targets for wetlands around the creeks. The effects of these measures easily cause water logging in nearby agricultural areas. Therefore fine-tuning of water system adjustments is needed to achieve optimal conditions for both high agricultural production and flourishing creek ecosystems. Possible measures were described resulting in an integrated approach for the optimisation of ecological conditions supporting the restoration of natural creek ecosystems within this agricultural environment.

\section{REFERENCES}

BROUWER F., HUININK J.T.M. 2002: Opbrengstdervingspercentages voor combinaties van bodemtypen en grondwatertrappen. HELP-tabellen en opbrengstdepressiekaarten [yield reduction percentages for combinations of soil type and groundwater regimes] (in Dutch) Report 493. Alterra, Wageningen/EC-LNV.

KUIJPER M.J.M., STROET C.B.M. 2003: Upgrading of non-linear drainage systems in MODFLOW models by the use of extremely detailed elevation data. Proceedings of the International Groundwater Modeling Conferrence MODFLOW and More 2003.

KUIJPER M.J.M., de LOUW P.G.B., BOUMA G.M., van WIRDUM G. 2006: Integrale gebiedsanayse Prinslandse Polders, achtergrondrapport [Integrated ecohydrological analysis of the
Prinslandse Polders] (in Dutch) TNOreport 2007-U-R0751A, Utrecht.

Province and Waterboards Noord-Brabant, 2002: Streefbeelden voor beken en kreken in Noord-Brabant. [Targets for streams and creeks in Noord-Brabant] (in Dutch).

STUURMAN R.J., de LOUW P.G.B. 2001: De toekomst voor brakke kwel in Brabantse kreken, een eerste verkenning [The future of brackish seepage in Brabant creeks] (in Dutch). TNO-report NITG 01-071-B, Delft.

WAMELINK W., RUNHAAR J. 2000: Abiotische randvoorwaarden voor natuurdoeltypen. [Abiotic boundary conditions for nature types] (in Dutch) Report 181. Alterra, Wageningen.

Streszczenie: Rekultywacja ekosystemów wód słonawych przy wykorzystaniu platformy zintergrowanego systemu wodnego. Większość cieków wciąż istniejących na obszarach holenderskich polderów o podłożu gliniastym, pomimo tego, iż aktualnie znajdują się na terenach intensywnie użytkowanych rolniczo, posiada wysoki potencjał ekologiczny, który może pozwolić na odtworzenie prawidłowo funkcjonujących ekosystemów. Podobnie jak większoość obszarów w Holandii, poldery o podłożu gliniastym również charakteryzują się wysoką gęstością zaludnienia. Dlatego też wielofunkcyjne wykorzystanie terenu jest tam stymulowane, będąc naturalną konsekwencją tego faktu, a różne sposoby użytkowania ziemi występują obok siebie na niewielkich obszarach. Rezultatem takiej sytuacji jest pojawianie się konfliktów związanych z zagadnieniami wodnymi: rolnicze wykorzystanie ziemi wymaga stosunkowo głębokiego zalegania poziomów wód gruntowych oraz przyczynia się do eutrofizacji systemu wodnego w wyniku wzmożonego dopływu substancji biogennych, podczas gdy ekosystemy znajdujące się w oraz wzdłuż wciąż istniejących cieków potrzebują warunków wodnych charakterystycznych dla obszarów mokradłowych oraz niskiego poziomu substancji biogennych. Co więcej, okresy wysokich stanów i przepływów wód powoduja zalewanie i powodzie na obszarach wykorzystywanych rolniczo. Nadzwyczajne środki, takie jak zmniejszanie głębokości rowów melioracyjnych 
i cieków oraz podnoszenie poziomu wody, są konieczne, aby wzdłuż cieków osiągnąć stosunki wodne właściwe dla obszarów mokradłowych. Z drugiej jednak strony, efekty wprowadzenia takich nadzwyczajnych środków z dużym prawdopodobieństwem mogą prowadzić do gromadzenia się wody i podtapiania położonych w pobliżu obszarów wykorzystywanych rolniczo. W niniejszym artykule zaprezentowany został zintegrowany sposób rozwiązania zagadnienia rekultywacji ekosystemów cieków wodnych znajdujących się na obszarach o wyżej przedstawionej charakterystyce. Przy opracowywaniu takiego rozwiązania, zarówno złożone relacje i interakcje pomiędzy wodami gruntowymi, powierzchniowymi oraz elementami ekologicznymi, jak również warunki ograniczające wynikające z rolniczego wykorzystania obszaru, sposobów rozwoju przestrzennego przyległych terenów, a także ramy prawne wynikające $\mathrm{z}$ takich aktów, jak na przykład Europejska Ramowa Dyrektywa Wodna, zostały wzięte pod uwagę. Zaproponowany, w wysokim stopniu zintegrowany, zespół możliwych środków i działań pozwala na uzyskanie optymalnych warunków zarówno dla osiagnięcia wysokiej produkcji rolniczej, jak i przywrócenia i utrzymania właściwego stanu ekosystemów wodnych.

MS. received November 2007

\section{Authors' address:}

Marijn Kuijper

TNO Geological Survey of The Netherlands, Princetonlaan 6, Utrecht, The Netherlands, ph+31(0)3025 64754, marijn.kuijper@tno.nl Perry de Louw

TNO Geological Survey of The Netherlands, Princetonlaan 6, Utrecht, The Netherlands, ph+31(0)3025 64806, perry.delouw@tno.nl 